\title{
Surfaces
}

\section{Rachel Bowlby, Still Crazy After All These Years, (New York \& London: Routledge, 1992)}

\section{Janice Stewart}

Volume 3, 1993

URI : https://id.erudit.org/iderudit/1065112ar

DOI : https://doi.org/10.7202/1065112ar

Aller au sommaire du numéro

Éditeur(s)

Les Presses de l’Université de Montréal

ISSN

1188-2492 (imprimé)

1200-5320 (numérique)

Découvrir la revue

Citer ce compte rendu

Stewart, J. (1993). Compte rendu de [Rachel Bowlby, Still Crazy After All These

Years, (New York \& London: Routledge, 1992)]. Surfaces, 3.

https://doi.org/10.7202/1065112ar d'utilisation que vous pouvez consulter en ligne.

https://apropos.erudit.org/fr/usagers/politique-dutilisation/ 


\title{
BOOK REVIEW
}

\author{
RACHEL BOWLBY: \\ STILL CRAZY AFTER ALL THESE YEARS
}

Janice Stewart

\section{Rachel Bowlby, Still Crazy After All These Years, (New York \& London: Routledge, 1992)}

In Still Crazy After All These Years: Women, Writing and Psychoanalysis, Rachel Bowlby, vaguely following the route of The Post Card: From Socrates to Freud and Beyond, takes her readers on a whirlwind literary tour: from ancient Greece, through the streets of Paris with Huart and Baudelaire, along the roads of Balbec with Proust, shopping in the lanes of London with Woolf, into gloomy dead-ends with Rhys, through a small museum of feminist criticism with $m / f$ and Friedan, on turbulent flights between feminist idealities in France, Britain, and America, then back across the Atlantic to Jensen's Pompeii, and finally to the consulting room at 19 Bergrasse in Vienna. In each city of her tour, Bowlby searches for the female equivalent of the 'man on the street', but instead discovers "The passante, perhaps the most ancient and the most modern figure of a woman".11] The essays that comprise Bowlby's globetrotting travelogue critically consider both women on the street and women on the move and how "the texts written about them construct possibilities and limits, openings, and impasses?" (vii). Bowlby's own adventurous text, however, is undaunted by impasses and traverses many borders and boundaries in its good-humoured attempt to discover what a nice girl is doing in a place like this, and "Where do 'we' -- women? feminists? passantes? -- go from here?" (63).

Bowlby sets off on her critical journey with a walking and writing tour of nineteenth-century flânerie. Examining the traditional scopic economies of 
the literary flâneur and passante, Bowlby discovers that the flâneur is, in part, a sexual window-shopper, and women are "part of the spectacle, one of the curiosities in which the flâneur will want to take an interest in the course of his walking" (6). Like the articles noticed during window-shopping excursions, the passante is "merely or mostly the man's projection" (13): there is no real desire to closely examine 'the goods', simply the fantasy of the spectacle pleasingly presented and fleetingly glimpsed. Woman, as the object of the traditional modernist masculine gaze, is limited; she is a silent ephemeral apparition upon which the male flâneur/writer may comment. She is not a flâneuse capable of describing her own excursions through the streets. Bowlby, however, is not satisfied with simply noting the relative positioning of the passante, and urges her readers to "Look again, look at her as she really is, and you will see something very different from what appears from the perspective of the masculine writer...[or you might] look instead at the conditions of representation that made it possible for the woman to be seen as a passante (65).

Crossing the Channel, and wandering through A Room of One's Own, Mrs. Dalloway, and Woolf's Collected Essays, Bowlby discovers that in Woolf's texts "the passante has become the mobile spectator herself, not the one who is glimpsed at, her active looking making an implicit contrast with what now appears to have been the passivity of the woman seen by the masculine flâneur" (22-23). Bowlby examines Woolf's written exodus into the streets of London as both "a question of progress, forward along a given line, or a question of transgressiveness implicit in the position outside that of masculine normality" (30).

Bowlby's expedition is not, however, a feminist Potemkin tour. Having established women's ability to enter, follow, or trespass upon the masculine byways of observation and writing, Bowlby stops short along that same byway to explore a woman trapped within a fictional impasse in Good Morning Midnight. The impasse of Rhys' novel is the narrator's very selfconsious adherence to the planned and mapped "literary streets already well-trodden by men" (viii). "Rhys and Woolf bring into sharp focus the difficulty of moving away from a story that seems to have structured the sexual scene once and for all" (59). Bowlby argues that "This impasse with the exit blocked, forces you to enter the show,to make a spectacle of yourself. Sasha's encounters with men will all turn around a question of who is exhibiting what to whom, who is the buyer and who is the seller" (46). The traditional scopic economy of flânerie is disrupted, but not overturned: it is the hitherto seemingly aimless passante (Sasha) who is given the narrative voice, and there is ambiguity as to who is watching/writing whom.

After opening the melancholy impasse of Rhy's novel, Bowlby moves on to examine theoretical perspectives of women's subjectivity, or the art of flânerie institutionalized. Bowlby believes that "The Freudian/Lacanian line treats the woman/ passante as the masculine fantasy of femininity" (63) and, 
somewhat ironically, treats the unconscious not unlike the modernist fleeting image of the passante. Turning down a different avenue of analysis to $\mathrm{m} / \mathrm{f}$, Bowlby admires the editors of the journal for voicing their resistance, in the editorial of issue 4 , to the flâneurs' tendency to systematically collectivize and generalize widely diversified women into a falsely coherent and universalized essentialist fantasy of "woman". Unlike Modernist flânerie, in which "one passante is like another in that she can be replaced, that another and another will figure in the same way, without there being any single constitutive event, even in retrospect" (11), the editors of $\mathrm{m} / \mathrm{f}$ refuse to accept individual women as collective supplements, and thereby force a reconstruction of feminine presence:

Mothers, workers, lesbian, battered wives, etc.'-- this particular collectivity is almost the exact antithesis of the passante, the negative of the fantasy of 'woman'. These women do no flit by, a look but not a word, instead they form a potentially endless line (etc.') walking the social streets assorted 'interests' with nothing to consolidate their common identity as woman (69).

Ironically, Bowlby finds that the fleeting passage of $m / f$ is akin to that of the passante, but unlike the easily forgotten or replaced Modernist passante, "the questioning of woman after $m / f$ `s passing can no longer be what it was" (74).

Bowlby, who has already taken us Shopping With Freud, now takes us shopping with Friedan. Bowlby's re-reading of The Feminine Mystique (1963), critically explores Friedan's treatment of, and susceptibility to, the impact of consumerism. Friedan believes that the early 'pioneer' feminists won their battle for equality, but that Freud, 'sex-directed educators', and especially Madison Avenue marketing executives, effectively reduced the feminist stronghold to ruins. Bowlby takes issue with Friedan's univocal collectivization of women, her denigration of 'feminine' occupations, and blatant homophobia. Bowlby, however, refuses to allow The Feminine Mystique to be a frustrating impasse, and instead turns it into an interesting detour which by "drawing attention to the inevitability of such unequal and unpredictable developments in the histories of feminism and its definitions of femininity, ...shows how unresolved questions may themselves be the most suggestive clues to what remains 'the problem with no name'" (93). Friedan's argument that women were sold out by Madison Avenue leads Bowlby to ask whether the various discourses of feminist criticism have become marketable commodities vying for consumer loyalty. Bowlby finds "that the question of whether or not you 'buy' an argument is already part of the problem, suggesting that an argument is something comparable to a finished product, to be taken or rejected as it is, according to whether it seems to satisfy our demand" (101). Bowlby advises her readers that what may at first appear as feminist bargains may in fact be well packaged and cleverly marketed seconds which have been marked for a quick sale. Feminists, whom Bowlby notes have become a key target for the marketing agencies, will still have favourites amongst the products which make their 
teeth and whites whiter, their hair and cars shinier, and their breath and rooms fresher, but to unreservedly 'buy into' a discourse because of its social status, availability, or self-indulgence is to be persuaded by advertising.

After discussing the marketability of feminist criticism, Bowlby confronts the oceanic distance between French and Anglo-American feminist criticism, and wonders if

this framework for the articulation of feminist issues may now have become too settled, repeated and regularised as it is in a form not so dissimilar to that same hierarchical binary fixity rightly criticised when it issues form the position of western, or American, logocentric masculinity. (110)

Bowlby's incisive analysis, which leaves neither camp unscathed, is tempered with an ever-present sense of good humour and willingness, perhaps even eagerness, to see the strong points of both sides. Bowlby seems to encourage a re-evaluation of the battle lines which have been drawn between the two dominant feminist factions. Only a few pages after warning her readers that feminist criticism often embodies elements which are self-promoting, Bowlby espouses the benefits of at least a partial transAtlantic reconciliation in a collection of essays which evidence a confluence of French and Anglo-American thought. However, Bowlby is not caught within her own rhetorical trap, for throughout the tour, she has constantly urged her readers to examine any text, presumably including her own, critically and sceptically.

Perhaps it is within the essay which has given Still Crazy After All These Years: Travels in Feminism and Psychoanalysis its name that Bowlby has the most fun. In an incredibly playful performance, Bowlby argues that feminism and psychoanalysis are more closely linked than the analysts of either school really wish them to be. Bowlby plays with Freud's oft-cited and derided "Fragment of an Analysis of a Case of Hysteria", but seriously points out that Dora may be seen either as the first feminist protestor against an analysis which did little more than re-inscribe the prevailing masculine norms of sexuality, or, as the starting point for researches which would challenge every essentialist patriarchal assumption of sexual pre-destination. Dora, to some extent, is the written passante who is briefly glimpsed at, misinterpreted as the embodiment of a heterosexual male fantasy, and lost into a hazy realm of past possibilities never exercised. Dora, however, is not a passive passante, and refuses to allow the Freudian flâneur to continue to watch/write/create her from his own perspective. Exemplary of the humour that Bowlby brings to her commentary on the psychoanalytic feminist nexus is her assurance that throughout her own sometimes misdirected pursuit of 
psychoanalytic understanding and explication, "I can honestly say, though, that whenever I saw a cat I took no further steps and merely called it a cat, mewtatis mutandis, or even (perhaps) per os." Within this sentence, the likes of which are generously scattered throughout the collection of essays, Bowlby humorously evokes an history of feminist, literary. linguistic, and psychoanalytic commentary, from Freud to Gallop, and demonstrates her own sophisticated attitudes to calling a pussy a pussy.

Leaving "Dora" behind closed Lacanian doors, Bowlby, with a nod to Rhy's impasse and the journey motif, brings her critical caravan back to the ancient Mediterranean, where we began our tour with a "footnote" on Aristophanes' version of the origin of the sexes. In Pompeii with Jensen's Gradiva and Freud, Bowlby finds that although Gradiva "is in one sense the passante story come true (162), in "Freud's study of Wilhelm Jensen's novella, it is the girl who seems to have it all, while it is the man who is deluded, divided, and in need of help" (158). Zoe initially appears as the unattainable and ephemeral passante, but rather than tractably accepting the masculine gaze, she returns "to bring him out of the fantasy of imagining her as something dead, unattainable, belonging to a past life, and reveal that she stands for the possibility of love and life in the here and now" (163). Although Freud stumbles into several disappointing impasses and patriarchal ruts whilst commenting upon Zoe's powers to excel as a healing force, his own theories can be used to tear down the normalised perception of Zoe as simple creature whose ultimate goal is to be a woman in love with a man.

Like most travel brochures, or perhaps worse an aunt's slide-show of her vacation, this brief synopsis of Bowlby's journey through times, places, and pages is only the briefest hint of the experience to be gained by taking the actual journey. Still Crazy after all these Years: Women, Writing and Psychoanalysis revivifies the forgotten, or ignored, links between feminism and psychoanalysis in a marvellously good humoured and subtly incisive examination of women's subjectivity. Like Gradiva, Bowlby "steps in on the established patterns of thinking with the assurance of her irony: playing for change, and playing in all seriousness" (x).

\section{Janice Stewart}

\section{Etudes anglaises}

\section{Université de Montréal}


Surface Page d'Acceuil/Home Page

[1]Rachel Bowlby, Still Crazy After All These Years: Women, Writing \& Psychoanalysis (London: Routledge, 1992) 65. 